\title{
New Insights as to Why Progesterone Receptor Modulators, such as Mifepristone, Seem to Be More Effective in Treating Cancers that Are Devoid of the Classical Nuclear Progesterone Receptor
}

\author{
JEROME H. CHECK ${ }^{1,2}$ and DIANE CHECK ${ }^{2}$ \\ ${ }^{1}$ Department of Obstetrics and Gynecology, Division of Reproductive Endocrinology \& Infertility, \\ Cooper Medical School of Rowan University, Camden, NJ, U.S.A.; \\ ${ }^{2}$ Cooper Institute for Reproductive Hormonal Disorders, P.C., Mt. Laurel, NJ, U.S.A.
}

\begin{abstract}
Mifepristone treatment for advanced cancer has demonstrated considerable improvement in both length and quality of life in patients who no longer have any other treatment options. The target is the progesterone induced blocking factor $(P I B F)$, which helps the tumor to invade the normal tissue and proliferate and suppress cellular immunity. Most of the benefit has been observed in cancers not associated with the classical nuclear progesterone receptor $(n P R)$. There are data showing that the presence of a nPR may be associated with a better prognosis. Membrane PRs seem to be responsible for PIBF secretion. Mifepristone, possibly fails to block another $P$ associated protein that enables the tumor to proliferate, e.g., the progesterone receptor membrane component-1 (PGRMC-1) protein. One hypothesis is that the nPR helps to inhibit tumor production of PGRMC-1 protein. Thus, mifepristone may inhibit tumor spread by suppressing PIBF, but this may be negated by blocking the $n P R$, allowing PGRMC-1 levels to increase.
\end{abstract}

This article is freely accessible online.

Correspondence to: Jerome H. Check, MD, Ph.D., Department of Obstetrics and Gynecology, Division of Reproductive Endocrinology \& Infertility, Cooper Medical School of Rowan University, 7447 Old York Road, Melrose Park, PA 19027, U.S.A. Tel: +1 2156354156, Fax: +1 2156352304, e-mail: laurie@ccivf.com

Key Words: Progesterone induced blocking factor, progesterone receptor membrane receptor component-1, immunomodulatory proteins, tumor microenvironment, cellular immunity, review.
One potential ideal target that is needed for the fetal semiallograft to proliferate, invade normal tissue, and escape immune surveillance is called the progesterone induced blocking factor (PIBF) (1-9). The main sources for PIBF in the fetal placental microenvironment are embryonic, mesenchymal, and trophoblast cells (8). In addition, PIBF can be made by circulating gamma/delta T-cells as evidenced by a rise in serum PIBF following progesterone (P) exposure even in males (10). The levels secreted in the microenvironment are probably insufficient to cause an increase in serum PIBF levels.

\section{Could PIBF Be the Magical Protein Needed by the Fetus and Malignant Tumor to Aid in Cell Proliferation, Tissue Invasion, and/or Escape from Immune Surveillance, But Not Required After Birth for Normal Physiologic Functions?}

At a time when the PIBF protein had not been fully synthesized, one could create only a polyclonal antibody to PIBF (as opposed to a monoclonal antibody). Thus, PIBF secretion by an enzyme-linked immunoassay (ELISA) method could not be evaluated; therefore, an immunocytochemistry method was developed to measure PIBF. The blood from 50 patients with various types of cancer in various stages of disease was evaluated for the presence of circulating lymphocytes expressing the PIBF protein. The mean percentage of lymphocytes expressing PIBF was $0.3 \%$ for these 50 cancer patients compared to only $0.05 \%$ for 62 controls without cancer (11). The highest \% of PIBF expressing lymphocytes was $6.7 \%$ in a patient with cancer, whereas the highest $\%$ in a control was $1.7 \%$ (11). This study, published in 
2001, was the first bit of evidence that PIBF could be a very important target for cancer therapy (11). One speculation was that if the protein could be purified, and then synthesized, it could lead to immunotherapy with monoclonal antibodies against PIBF (11). An alternative consideration could be the use of a progesterone receptor antagonist (or modulator), if the production of PIBF requires interaction of progesterone $(\mathrm{P})$ or some type of progestin with either the classical nuclear $\mathrm{P}$ receptor or a membrane $\mathrm{P}$ receptor (11).

Considering which of these two treatment options to evaluate for inhibiting cancer proliferation and spread, and prolong and improve quality of life, the use of a $\mathrm{P}$ antagonist was considered the more practical option, since one of these selective $\mathrm{P}$ receptor modulators, mifepristone, was already on the pharmaceutical market and approved as an abortifacient (11).

The problem with treating with mifepristone was that there were unimpressive results from previous clinical trials using mifepristone for cancers known to be associated with the classical nuclear progesterone receptor (PR), e.g., breast, ovarian, and endometrial cancer (12-18). Since selective estrogen receptor (ER) modulators, e.g., tamoxifen, was found to have a beneficial effect on inhibiting ER positive breast cancer, it was thought that the presence of the classical nuclear ER was somehow needed for the cancer to progress. Thus, it was suggested that the nuclear (n) PR may be needed for tumor progression.

\section{The Presence of the Classical nPR in Certain Cancers and Subsequent Prognosis}

Actually, the presence of the classical nPR has been associated with a more favorable prognosis in women with breast cancer (19-21). Similarly, the presence of the classical $\mathrm{nPR}$ in endometrial and ovarian cancer has also been associated with a better prognosis $(22,23)$.

This led to the hypothesis that if the presence of PIBF is an important factor in allowing tumor growth and metastases, perhaps mifepristone does suppress this protein, but it also may suppress some other anti-cancer factor protective substance that requires activation of the nPR. Down-regulation of this hypothesized anti-tumor factor could negate some of the beneficial effect of suppressing PIBF production. However, it is also possible that tumor production of PIBF is accomplished through some other mechanism that bypasses the PR. Thus, the next logical study would be to determine if there is evidence of PIBF expression in cancers not known to be associated with the $\mathrm{nPR}$, and to determine if this PIBF protein could be suppressed by mifepristone treatment. If PIBF could be demonstrated to be produced by cancer cells, despite the absence of the classical nPR, it could support the concept that PIBF expression may be operating through rapid signaling membrane (m) PRs rather than nPRs (24-28).

\section{Detection of PIBF Expression in Human Leukemia Cell Lines, and the Effect of Mifepristone on PIBF mRNA and Protein Expression}

If the mPR is involved in PIBF expression, then the question that arises is whether $\mathrm{P}$ secretion is necessary for stimulation of the mPR to cause PIBF expression, or if there is a $\mathrm{P}$ independent mechanism. Serum levels of PIBF secreted by circulating gamma/delta $\mathrm{T}$ cells seem to be directly related to serum P levels (29). Cancer is not associated with an increase in serum $\mathrm{P}$ levels. Thus, it is not surprising that there is no increase in serum PIBF in patients with cancer, even with the presence of classical nPRs $(30,31)$.

If PIBF is used by cancer cells to escape immune surveillance, and even help to increase cellular proliferation rate and tissue invasion, it would seem likely that the source should be the cancer cells themselves. Local production of $\mathrm{P}$ by cancer cells would likely be insufficient to raise serum $\mathrm{P}$ levels, and thus insufficient to raise serum PIBF levels. However, small amounts of $\mathrm{P}$ production by cancer cells may be sufficient to produce PIBF in the tumor microenvironment. There are data showing that most tumors may secrete hCG, thus providing a mechanism for $\mathrm{P}$ production by cancer cells (32-34).

To evaluate if cancer cells can express PIBF, and to determine if mifepristone can suppress PIBF expression in cancers devoid of the classical nPR, human leukemia cell lines were chosen as the test model. Twenty-two leukemia cell lines including B-cell lines, T-cell lines, and myeloid cell lines, were evaluated for PIBF messenger (m) RNA and protein expression. Not only did all these leukemia cell lines produce PIBF mRNA, but PIBF mRNA had the highest concentration compared to other mRNAs in Dr. Srivastava's 40 years'experience evaluating protein synthesis from leukemia cell lines (35). Ten of these cell lines representing major cell lineages were selected for PIBF staining. Though a more sensitive anti-PIBF antibody had not been developed as yet, PIBF expression was detected in 4 of the 10 cell lines. The three cell lines with the highest PIBF protein expression were evaluated for the effect of adding $\mathrm{P} v s$. mifepristone to the media. Whereas adding $\mathrm{P}$ up-regulated PIBF mRNA and protein expression, mifepristone suppressed PIBF protein and mRNA expression (35). Three of the four leukemia cell lines used to evaluate the effect of $\mathrm{P} v s$. mifepristone on PIBF levels demonstrated the presence of mPRs, but not nPRs (36).

Prior to this study on leukemia cell lines, Lachman et al., demonstrated that PIBF was released to the extracellular component not only in cancers known to be associated with the classical nPR, e.g., uterine, ovarian, and breast cancer, but also cancers, such as those of the stomach, cervix and brain, which are not known to be associated with the classical nPR (10). The study by Srivastava et al., and Lachman et al., support the concept that PIBF may exert its action predominantly in the tumor microenvironment $(8,11,35)$. 


\section{Further Support for PIBF Expression by Cancer Cells}

Six different human glioblastoma multiforme cancer cell lines were also shown to express PIBF (37). However, in this case the PIBF splice variant measured $57 \mathrm{kDa}$. Similar to the data from leukemia cell lines, adding $\mathrm{P}$ to the medium led to up-regulation of PIBF expression, whereas the addition of mifepristone down-regulated PIBF expression (37).

The evidence strongly suggests that the main action of the splice variant of PIBF seems to be to suppress cellular immunity (38). Thus, if the role of PIBF was strictly to inhibit immune surveillance, the drug would not be likely to inhibit cancer cell proliferation because of the absence of an intact immune system, and the absence of effector white blood cells. However, there is evidence that the parent $90 \mathrm{kDa}$ protein is involved in cell cycle regulation and thus, may play a role in proliferation and tissue invasion (8). Indeed, mifepristone has been found to inhibit the growth of cancer cell lines known to be associated with the nPR, e.g., endometrial and ovarian cancer (39-43). Mifepristone has also suppressed the growth of malignant tumor cell lines not associated with the classical nPR, including gastric, lung, and other cancers of nonreproductive organs $(44,45)$.

\section{Controlled Murine Studies Evaluating the Efficacy of Mifepristone in Treating Various Malignancies Not Known to Be Associated With the Classical nPR}

Though cell line studies are important, the translation to clinical use does not always happen. This may be related to the dosage of mifepristone being a lot higher in cancer cell line studies $v s$. the level obtained with treatment of the intact animal or human. Also, as mentioned, cancer cell line studies do not take into account the potential benefit of mifepristone in facilitating immunosurveillance.

Controlled placebo studies were conducted, evaluating the efficacy of mifepristone $v s$. control on longevity and quality of life (as determined by body conditioning scores) in mice bred to have a high frequency of certain specific cancers. Clinical benefit was demonstrated in murine leukemia, lung, and testicular cancer, which were selected because they were not known to be associated with the nPR (46-48).

Benefits were also seen in murine prostate cancer (48). Prostate cancer has been associated with the PR. Similar to breast, ovarian, and endometrial cancer, reduced nPR expression in prostate cancer associated stroma can be conducive to a tumor microenvironment favorable for cancer cell invasion and tumor metastases (49). It is not known however, if the $\mathrm{C} 87 \mathrm{BL} / 6$ mice used for this study were positive for the nPRs (48).

\section{The Efficacy of Mifepristone Treatment in Human Cancers Without Evidence of a nPR}

Though mifepristone has been available on the world's pharmaceutical market, because it was first approved as an abortifacient, and with the consideration of the sensitivity of many anti-abortion groups, a physician, at least in the United States, must either obtain a grant for a research study to use the drug for cancer therapy or apply for a compassionate use investigative New Drug Approval (NDA) on a case-by-case basis. In general, approval was mainly given for advanced end-stage metastatic cancers that failed all other treatment options. One exception was a man with multifocal renal cell carcinoma where there were no chemotherapy options at that time. He is now 19 years from his initial mifepristone therapy, and is doing well (50).

The improved longevity and improved quality of life with mifepristone treatment despite previous progression despite surgery, radiotherapy, chemotherapy, immunotherapy, and targeted therapy, has lasted, in some cases, years, rather than months. Frequently in those who died, the cause was something other than the cancer itself. Some of these types of advanced cancers in which patients have experienced years of good quality of life following mifepristone therapy include colon cancer, thymic epithelial cell cancer, small cell lung cancer, non-small cell lung cancer, leiomyosarcoma, and pancreatic cancer (51-58). In one woman with probable small cell lung cancer with marked hypoxia and hyponatremia related to the syndrome of inappropriate antidiuretic hormone, in a very short period of time all the lung lesions disappeared, and her partial pressure of oxygen ( $\mathrm{PaO} 2)$ became normal, as did her serum sodium levels (59).

Though sometimes the malignant lesions regress completely or decrease in size, more often they remain stable, the patient demonstrates improved quality of life, and although tumor growth may continue (but usually without more metastases), the rate of growth is considerably slower. All the aforementioned cases of non-small cell lung cancer had brain metastases and in the many years they lived while on mifepristone therapy, there has not been any return of their brain metastases, and their local lung lesions, especially the primary lesion, grew very slowly.

In other instances, such as in transitional cell carcinoma of the renal pelvis, malignant fibrous histiocytoma, and glioblastoma multiforme stage IV, mifepristone treatment resulted in some objective evidence of efficacy, especially improvement in quality of life rather than longevity, $(52,60)$. Even though these patients had such advanced cancers that many were moribund, mifepristone provided increased longevity or palliative benefits in the majority of cases. It should be recalled that it was started after all other available treatments had failed and there were no other treatment options. 


\section{Could the P Receptor Membrane Component-1 (PGRMC-1) Protein Help Explain the Apparent Difference in the Efficacy of Mifepristone for Cancers Associated, or Not Associated, With the Classical nPR?}

The PGRMC-1 protein is present at various subcellular locations, e.g., plasma membrane, endoplasmic reticulum Golgi apparatus, nucleus, and acrosomal membrane (61). It is a $25 \mathrm{kDa}$ multifunctional protein. One of its functions is to induce $\mathrm{P}$ signaling (62). This may enable the small amounts of $\mathrm{P}$ secreted to have a greater reaction with mPRs. Thus, it could enhance PIBF secretion, which could not only suppress immune surveillance by NK cells and cytotoxic T-cells in the tumor microenvironment, but also enable more rapid proliferation of the cancer cells and foster tissue invasion.

PGRMC-1 may increase cancer aggressiveness in other ways than through PIBF, since it regulates cell proliferation and apoptosis through interaction between its cytochrome $\mathrm{b}$ 3 binding domain and other binding partnering, e.g., epidermal growth factor receptor, $\mathrm{P} 450$ protein, and plasma activator RNA binding protein (63-66). Other functions include steroidogenesis, vesicle trafficking, mitotic spindle and cell cycle regulation, promotion of autophagy, angiogenesis, anchorage independent growth, invasive growth, and hypoxic biology (67).

Some data suggest that PGRMC-1 protein production by cancer cells may increase cancer aggressiveness by suppressing the p53 and WnT/B-catenin pathways, thus promoting human pluripotent stem cell self-renewal (68). The PGRMC-1 protein and mRNA have not only been detected, but up-regulated, in various malignancies, including breast, ovary, cervix, and colon (69-72). Upregulated PGRMC-1 expression has been found to correlate with poor overall survival, poor quality of life, and decreased tumor-free interval $(71,73-75)$.

One hypothesis to explain why mifepristone may not be as effective for cancers positive for the classical nPR is that the mifepristone may be suppressing PIBF by inhibiting mPRs, but if the nPRs help to suppress PGRMC-1 protein, mifepristone could up-regulate PGRMC-1, thus negating some of its benefits.

The PGRMC-1 protein seems to be stimulated by $\mathrm{P}$ and thus, a beneficial effect of mifepristone on suppressing PIBF and PGRMC-1 may be expected (76). It should be recalled that mifepristone is not a pure PR antagonist, but a modulator, which means it may suppress some PRs in some tissues, but not in others, or it may suppress the PR at a higher concentration but possibly act as an agonist at a lower concentration. Cancer cell line studies show that mifepristone, at a higher concentration, inhibits PGRMC-1 protein expression. However, at a lower concentration, similar to that achieved with a daily dosage of 200-300 $\mathrm{mg}$ /day of mifepristone, mifepristone may actually cause an increase in PGRMC-1 levels, yet be sufficient to suppress PIBF expression (76).

Of course, there is the possibility that the nPR in some way affects some other protein, or factor, other than PGRMC-1, that limits tumor aggressiveness. There is also the possibility that mifepristone was actually more effective than the conclusion reached by these early aforementioned studies, since in those days, the primary endpoints were objective response based on tumor regression. Possibly if the primary endpoints had been longevity and quality of life, they may have concluded that mifepristone showed efficacy even in cancers associated with the nuclear $\mathrm{P}$ receptor.

We have had limited exposure in treating very advanced breast cancer with mifepristone. One 45-year-old man who had end-stage breast cancer, with probable imminent death pending, and no other treatment options, was started on mifepristone. He died 6 weeks later, therefore, we cannot state that the drug helped to prolong life. However, he stated that the drug provided marked relief of his pain and fatigue.

A 37-year-old woman with end-stage breast cancer that had metastasized widely despite surgery, radiotherapy, and chemotherapy with dose-devise doxorubicin cyclophosphamide Palbociclib/letrozole followed by everolimus/fulvestrant, with subsequent extensive liver and bowel metastases, was given intravenous cyclophosphamide, methotrexate, and 5fluorouracil followed by capecitabine. Due to a Plk3 mutation, she was next treated with alpelisib with fulvestrant. The disease continued to progress with more peritoneal and liver metastases and new bone metastases.

She consulted with our group for mifepristone therapy. The oncologist advised her not to stop the alpelisib. Unfortunately, the combination caused severe hypokalemia (77). She chose to stop the alpelisib and take single agent mifepristone $200 \mathrm{mg} /$ day orally.

After one month of single agent mifepristone at her evaluation she said she felt better during this month than she had felt in several years.

Nevertheless, her oncologist advised her to stop the mifepristone because her tumor markers were increasing. He restarted alpelisib, even though her tumor markers increased with this drug previously also, and her breast cancer showed marked advancement. Her suffering returned while on alpelisib and she was placed on hospice, and died shortly thereafter. This case is an example where the oncologist may have been disappointed in the efficacy of mifepristone because of increasing tumor markers, but from a symptomatic standpoint, it worked better than any drug she had been previously taking. Mifepristone is extremely well tolerated, with few side effects when using it at the 200 $\mathrm{mg} /$ day dosage (78). 


\section{Future Direction for Anti-cancer Drugs Based on Knowledge of PIBF and PGRMC-1 Protein}

Though mifepristone is already on the pharmaceutical market, unfortunately its use as an anti-cancer agent is not well known to most oncologic physicians. Pharmaceutical companies that produce this drug do not seem interested in investing money for clinical studies possibly because they may not be able to patent the drug for cancer use.

However, there are avenues that pharmaceutical companies can pursue to develop a new drug that could be patented, which could be more effective than mifepristone. For example, the hypokalemia from the breast cancer case resulting from the combination of mifepristone and alpelisib was probably related to the alpelisib interfering with the metabolism of the mifepristone, resulting in a higher concentration of mifepristone (77). At high dosages, mifepristone also blocks the glucocorticoid receptor. If mifepristone could be used in higher dosages it will likely block both PIBF and PGRMC-1. Thus, pharmaceutical companies can develop a pure PR receptor antagonist that has no or only a very weak effect on the glucocorticoid receptor.

Another direction for pharmaceutical companies is to develop a monoclonal antibody directed against PIBF, now that the pure protein can be synthesized. If the hypothesis is correct that mifepristone is less effective for cancers associated with the nPR by negating the possible beneficial role of the nPR in suppressing certain cancer promoting factors, e.g., the PGRMC-1 protein, then a monoclonal antibody against PIBF would not negate the beneficial effect of the nPR in suppressing PGRMC-1.

Another area to explore would be to combine mifepristone with another drug that suppresses PGRMC-1, e.g., AG205 (79). This, theoretically, would benefit not only cancers positive for the nPR, but even those cancers devoid of the nPR. As mentioned, it is common to see patients who are responding well to mifepristone with prevention of metastatic spread to still be plagued by slow growth of some of their lesions especially the primary lesion. This could be related to mifepristone at lower dosages not only failing to inhibit PGRMC-1, but possibly even acting as an agonist, and thus up-regulating PGRMC1 protein production.

There is evidence that a common time for tumors to metastasize may be at the time of surgery. This may be from tumor cells escaping from the tumor being excised or by temporary suppression of the immune system from the surgery and/or anesthesia (80). Perhaps future studies may consider the efficacy of using mifepristone for a month before and a month or two after surgery to see if this may inhibit later metastases or recurrence.

\section{Conflicts of Interest}

The Authors have no conflicts of interest to declare regarding this manuscript

\section{Authors'Contributions}

The majority of the manuscript was written by the lead author and modifications of the manuscript were made by Diane Check. Diane Check also runs the clinical cancer studies.

\section{References}

1 Szekeres-Bartho J, Chaouat G and Kinsky R: A progesteroneinduced blocking factor corrects high resorption rates in mice treated with antiprogesterone. Am J Obstet Gynecol 163(4 Pt 1): 1320-1322, 1990. PMID: 2220944. DOI: 10.1016/00029378(90)90713-h

2 Check JH, Szekeres-Bartho J and O'Shaughnessy A: Progesterone induced blocking factor seen in pregnancy lymphocytes soon after implantation. Am J Reprod Immunol 35(3): 277-280, 1996. PMID: 8962661. DOI: 10.1111/j.16000897.1996.tb00045.x

3 Check JH, Arwitz M, Gross J, Szekeres-Bartho J and Wu CH: Evidence that the expression of progesterone-induced blocking factor by maternal T-lymphocytes is positively correlated with conception. Am J Reprod Immunol 38(1): 6-8, 1997. PMID: 9266004. DOI: 10.1111/j.1600-0897.1997.tb00269.x

4 Pence H, Petty WM and Rocklin RE: Suppression of maternal responsiveness to paternal antigen by maternal plasma. J Immunol 114(1 Pt 2): 525-528, 1975. PMID: 123259.

5 Szekeres-Bartho J, Kilaŕ F, Falkay G, Csernus V, Török A and Pacsa AS: The mechanism of the inhibitory effect of progesterone on lymphocyte cytotoxicity: I. Progesterone-treated lymphocytes release a substance inhibiting cytotoxicity and prostaglandin synthesis. Am J Reprod Immunol Microbiol 9(1): 15-18, 1985. PMID: 3863495. DOI: 10.1111/j.1600-0897.1985.tb00334.x

6 Szekeres-Bartho J, Barakonyi A, Polgar B, Par G, Faust Z, Palkovics T and Szereday L: The role of gamma/delta $T$ cells in progesterone-mediated immunomodulation during pregnancy: a review. Am J Reprod Immunol 42(1): 44-48, 1999. PMID: 10429766. DOI: 10.1111/j.1600-0897.1999.tb00464.x

7 Faust Z, Laskarin G, Rukavina D and Szekeres-Bartho J: Progesterone-induced blocking factor inhibits degranulation of natural killer cells. Am J Reprod Immunol 42(2): 71-75, 1999. PMID: 10476687.

8 Lachmann M, Gelbmann D, Kálmán E, Polgár B, Buschle M, Von Gabain A, Szekeres-Barthó J and Nagy E: PIBF (progesterone induced blocking factor) is overexpressed in highly proliferating cells and associated with the centrosome. Int J Cancer 112(1): 5160, 2004. PMID: 15305375. DOI: 10.1002/ijc.20326

9 Polgar B, Kispal G, Lachmann M, Paar C, Nagy E, Csere P, Miko E, Szereday L, Varga P and Szekeres-Bartho J: Molecular cloning and immunologic characterization of a novel cDNA coding for progesterone-induced blocking factor. J Immunol 171(11): 5956-5963, 2003. PMID: 14634107. DOI: 10.4049/ jimmunol.171.11.5956

10 Check JH, DiAntonio A, Check DL, Dougherty MP and DiAntonio G: A study to determine if estrogen (E) is needed to 
induce de novo progesterone $(\mathrm{P})$ receptors on gamma/delta $\mathrm{T}$ cells as evidenced by determining the degree of rise of progesterone induced blocking factor (PIBF) following $\mathrm{P}$ exposure in males. Clin Exp Obst Gyn 47: 419-420, 2020. DOI: 10.31083/j.ceog.2020.03.5078

11 Check JH, Nazari P, Goldberg J, Yuen W and Angotti D: A model for potential tumor immunotherapy based on knowledge of immune mechanisms responsible for spontaneous abortion. Med Hypotheses 57(3): 337-343, 2001. PMID: 11516226. DOI: 10.1054/mehy.2001.1333

12 Klijn JG, de Jong FH, Bakker GH, Lamberts SW, Rodenburg CJ and Alexieva-Figusch J: Antiprogestins, a new form of endocrine therapy for human breast cancer. Cancer Res 49(11): 2851-2856, 1989. PMID: 2720645.

13 Romieu G, Maudelonde T, Ulmann A, Pujol H, Grenier J, Cavalie G, Khalaf S and Rochefort H: The antiprogestin RU486 in advanced breast cancer: preliminary clinical trial. Bull Cancer 74(4): 455-461, 1987. PMID: 3311238.

14 Klijn JG, Setyono-Han B and Foekens JA: Progesterone antagonists and progesterone receptor modulators in the treatment of breast cancer. Steroids 65(10-11): 825-830, 2000. PMID: 11108894. DOI: 10.1016/s0039-128x(00)00195-1

15 Perrault D, Eisenhauer EA, Pritchard KI, Panasci L, Norris B, Vandenberg T and Fisher B: Phase II study of the progesterone antagonist mifepristone in patients with untreated metastatic breast carcinoma: a National Cancer Institute of Canada Clinical Trials Group study. J Clin Oncol 14(10): 2709-2712, 1996. PMID: 8874331. DOI: 10.1200/JCO.1996.14.10.2709

16 Ramondetta LM, Johnson AJ, Sun CC, Atkinson N, Smith JA, Jung MS, Broaddus R, Iyer RB and Burke T: Phase 2 trial of mifepristone (RU-486) in advanced or recurrent endometrioid adenocarcinoma or low-grade endometrial stromal sarcoma. Cancer 115(9): 1867-1874, 2009. PMID: 19241422. DOI: $10.1002 /$ cncr.24197

17 Rocereto TF, Saul HM, Aikins JA Jr and Paulson J: Phase II study of mifepristone (RU486) in refractory ovarian cancer. Gynecol Oncol 77(3): 429-432, 2000. PMID: 10831354. DOI: 10.1006/gyno.2000.5789

18 Rocereto TF, Brady WE, Shahin MS, Hoffman JS, Small L, Rotmensch J and Mannel RS: A phase II evaluation of mifepristone in the treatment of recurrent or persistent epithelial ovarian, fallopian or primary peritoneal cancer: a gynecologic oncology group study. Gynecol Oncol 116(3): 332-334, 2010. PMID: 19922989. DOI: 10.1016/j.ygyno.2009.10.071

19 Bardou VJ, Arpino G, Elledge RM, Osborne CK and Clark GM: Progesterone receptor status significantly improves outcome prediction over estrogen receptor status alone for adjuvant endocrine therapy in two large breast cancer databases. J Clin Oncol 21(10): 1973-1979, 2003. PMID: 12743151. DOI: 10.1200/JCO.2003.09.099

20 Pichon MF, Pallud C, Brunet M and Milgrom E: Relationship of presence of progesterone receptors to prognosis in early breast cancer. Cancer Res 40(9): 3357-3360, 1980. PMID: 7427948.

21 Dowsett M, Cuzick J, Wale C, Howell T, Houghton J and Baum $\mathrm{M}$ : Retrospective analysis of time to recurrence in the ATAC trial according to hormone receptor status: an hypothesisgenerating study. J Clin Oncol 23(30): 7512-7517, 2005. PMID: 16234518. DOI: 10.1200/JCO.2005.01.4829

22 Zhang Y, Zhao D, Gong C, Zhang F, He J, Zhang W, Zhao Y and Sun J: Prognostic role of hormone receptors in endometrial cancer: a systematic review and meta-analysis. World J Surg Oncol 13: 208, 2015. PMID: 26108802. DOI: 10.1186/s12957-015-0619-1

23 Zhao D, Zhang F, Zhang W, He J, Zhao Y and Sun J: Prognostic role of hormone receptors in ovarian cancer: a systematic review and meta-analysis. Int J Gynecol Cancer 23(1): 25-33, 2013. PMID: 23221605. DOI: 10.1097/IGC.0b013e3182788466

24 Valadez-Cosmes P, Germán-Castelán L, González-Arenas A, Velasco-Velázquez MA, Hansberg-Pastor V and CamachoArroyo I: Expression and hormonal regulation of membrane progesterone receptors in human astrocytoma cells. J Steroid Biochem Mol Biol 154: 176-185, 2015. PMID: 26275946. DOI: 10.1016/j.jsbmb.2015.08.006

25 Smith JL, Kupchak BR, Garitaonandia I, Hoang LK, Maina AS, Regalla LM and Lyons TJ: Heterologous expression of human mPRalpha, mPRbeta and mPRgamma in yeast confirms their ability to function as membrane progesterone receptors. Steroids 73(11): 1160-1173, 2008. PMID: 18603275. DOI: 10.1016/ j.steroids.2008.05.003

26 Valadez-Cosmes P, Vázquez-Martínez ER, Cerbón M and Camacho-Arroyo I: Membrane progesterone receptors in reproduction and cancer. Mol Cell Endocrinol 434: 166-175, 2016. PMID: 27368976. DOI: 10.1016/j.mce.2016.06.027

27 Zhu Y, Bond J and Thomas P: Identification, classification, and partial characterization of genes in humans and other vertebrates homologous to a fish membrane progestin receptor. Proc Natl Acad Sci USA 100(5): 2237-2242, 2003. PMID: 12601167. DOI: $10.1073 /$ pnas.0436133100

28 Pang Y, Dong J and Thomas P: Characterization, neurosteroid binding and brain distribution of human membrane progesterone receptors $\delta$ and \{epsilon\} (mPR $\delta$ and $\mathrm{mPR}$ \{epsilon\}) and $\mathrm{mPR} \delta$ involvement in neurosteroid inhibition of apoptosis. Endocrinology 154(1): 283-295, 2013. PMID: 23161870. DOI: 10.1210/en.2012-1772

29 Cohen RA, Check JH and Dougherty MP: Evidence that exposure to progesterone alone is a sufficient stimulus to cause a precipitous rise in the immunomodulatory protein the progesterone induced blocking factor (PIBF). J Assist Reprod Genet 33(2): 221-229, 2016. PMID: 26634256. DOI: 10.1007/s10815-015-0619-7

30 Check JH, Sarumi M, DiAntonio A, Hunter K, Simpkins G and Duroseau M: Serum levels of the progesterone induced blocking factor do not precipitously rise in women with gynecologic cancer in contrast to women exposed to progesterone. Clin Exp Obstet Gynecol 42(5): 563-567, 2015. PMID: 26524797.

31 Check JH, Rosenberg A, Check DL, DiAntonio A, Rui H, Cohen $\mathrm{R}$ and DiAntonio G: Serum levels of the immunomodulatory protein, the progesterone induced blocking factor (PIBF) which is found in high levels during pregnancy is not higher in women with progesterone $(\mathrm{P})$ receptor $(\mathrm{R})$ positive $v s$. negative breast cancer. Clin Exp Obstet Gynecol 44(2): 187-189, 2017. PMID: 29746019.

32 Acevedo HF, Tong JY and Hartsock RJ: Human chorionic gonadotropin-beta subunit gene expression in cultured human fetal and cancer cells of different types and origins. Cancer 76(8): 1467-1475, 1995. PMID: 8620425. DOI: 10.1002/10970142(19951015)76:8<1467::aid-cncr2820760826>3.0.co;2-a

33 Acevedo HF, Longinotti SM and Marquardt M: Expression of hCG, its subunits and fragments by human cultured cancer cells of the nervous system. Cancer Detect Prevent 19: 37, 1995.

34 Acevedo HG, Campbell-Acevedo GA, Buffin MK and Krichevsky A: In vivo expression of membrane-associated human chorionic 
human chorionic gonadotropin by cells isolated from cancerous human tissues. Proc Am Assoc Cancer Res 34: 27, 1994.

35 Srivastava MD, Thomas A, Srivastava BI and Check JH: Expression and modulation of progesterone induced blocking factor (PIBF) and innate immune factors in human leukemia cell lines by progesterone and mifepristone. Leuk Lymphoma 48(8): 1610-1617, 2007. PMID: 17701593. DOI: 10.1080/1042819 0701471999

36 Srivastava MD and Anderson DJ: Progesterone receptor expression by human leukocyte cell lines: molecular mechanisms of cytokine suppression. Clin Exp Obstet Gynecol 34(1): 14-24, 2007. PMID: 17447631.

37 Kyurkchiev D, Naydenov E, Tumangelova-Yuzeir K, IvanovaTodorova E, Belemezova K, Bochev I, Minkin K, Mourdjeva M, Velikova T, Nachev S and Kyurkchiev S: Cells isolated from human glioblastoma multiforme express progesterone-induced blocking factor (PIBF). Cell Mol Neurobiol 34(4): 479-489, 2014. PMID: 24474429. DOI: 10.1007/s10571-014-0031-3

38 Check JH and Cohen R: The role of progesterone and the progesterone receptor in human reproduction and cancer. Expert Rev Endocrinol Metab 8(5): 469-484, 2013. PMID: 30754194. DOI: $10.1586 / 17446651.2013 .827380$

39 Schneider CC, Gibb RK, Taylor DD, Wan T and Gerçel-Taylor $\mathrm{C}$ : Inhibition of endometrial cancer cell lines by mifepristone (RU 486). J Soc Gynecol Investig 5(6): 334-338, 1998. PMID: 9824816. DOI: 10.1016/s1071-5576(98)00037-9

40 Goyeneche AA, Carón RW and Telleria CM: Mifepristone inhibits ovarian cancer cell growth in vitro and in vivo. Clin Cancer Res 13(11): 3370-3379, 2007. PMID: 17545545. DOI: 10.1158/1078-0432.CCR-07-0164

41 Freeburg EM, Goyeneche AA, Seidel EE and Telleria CM: Resistance to cisplatin does not affect sensitivity of human ovarian cancer cell lines to mifepristone cytotoxicity. Cancer Cell Int 9: 4, 2009. PMID: 19222856. DOI: 10.1186/1475-2867-9-4

42 Gamarra-Luques CD, Goyeneche AA, Hapon MB and Telleria CM: Mifepristone prevents repopulation of ovarian cancer cells escaping cisplatin-paclitaxel therapy. BMC Cancer 12: 200, 2012. PMID: 22642877. DOI: 10.1186/1471-2407-12-200

43 Freeburg EM, Goyeneche AA and Telleria CM: Mifepristone abrogates repopulation of ovarian cancer cells in between courses of cisplatin treatment. Int J Oncol 34(3): 743-755, 2009. PMID: 19212679. DOI: 10.3892/ijo_00000200

44 Li DQ, Wang ZB, Bai J, Zhao J, Wang Y, Hu K and Du YH: Effects of mifepristone on proliferation of human gastric adenocarcinoma cell line SGC-7901 in vitro. World J Gastroenterol 10(18): 2628-2631, 2004. PMID: 15309708. DOI: 10.3748/wjg.v10.i18.2628

45 Zheng G, Shen Z, Chen H, Liu J, Jiang K, Fan L, Jia L and Shao $\mathrm{J}$ : Metapristone suppresses non-small cell lung cancer proliferation and metastasis via modulating RAS/RAF/MEK/MAPK signaling pathway. Biomed Pharmacother 90: 437-445, 2017. PMID: 28391165. DOI: 10.1016/j.biopha.2017.03.091

46 Check JH, Sansoucie L, Chern J, Amadi N and Katz Y: Mifepristone treatment improves length and quality of survival of mice with spontaneous leukemia. Anticancer Res 29(8): 29772980, 2009. PMID: 19661303.

47 Check JH, Sansoucie L, Chern J and Dix E: Mifepristone treatment improves length and quality of survival of mice with spontaneous lung cancer. Anticancer Res 30(1): 119-122, 2010. PMID: 20150625.
48 Check JH, Dix E, Wilson C and Check D: Progesterone receptor antagonist therapy has therapeutic potential even in cancer restricted to males as evidenced from murine testicular and prostate cancer studies. Anticancer Res 30(12): 4921-4923, 2010. PMID: 21187471.

49 Yu Y, Lee JS, Xie N, Li E, Hurtado-Coll A, Fazli L, Cox M, Plymate S, Gleave M and Dong X: Prostate stromal cells express the progesterone receptor to control cancer cell mobility. PLoS One 9(3): e92714, 2014. PMID: 24664419. DOI: 10.1371/journal.pone. 0092714

50 Check DL, Check JH and Poretta T: Conservative laparoscopic surgery plus mifepristone for treating multifocal renal cell carcinoma. Cancer Sci Res 3: 1-4, 2020. DOI: 10.33425/2639-8478.1053

51 Check JH, Dix E, Sansoucie L and Check D: Mifepristone may halt progression of extensively metastatic human adenocarcinoma of the colon - case report. Anticancer Res 29(5): 1611-1613, 2009. PMID: 19443374.

52 Check JH, Dix E, Cohen R, Check D and Wilson C: Efficacy of the progesterone receptor antagonist mifepristone for palliative therapy of patients with a variety of advanced cancer types. Anticancer Res 30(2): 623-628, 2010. PMID: 20332480.

53 Check JH, Check D, Wilson C and Lofberg P: Long-term highquality survival with single-agent mifepristone treatment despite advanced cancer. Anticancer Res 36(12): 6511-6513, 2016. PMID: 27919975. DOI: 10.21873/anticanres.11251

54 Check JH, Check D and Poretta T: Mifepristone extends both length and quality of life in a patient with advanced non-small cell lung cancer that has progressed despite chemotherapy and a check-point inhibitor. Anticancer Res 39(4): 1923-1926, 2019. PMID: 30952734. DOI: 10.21873/anticanres.13301

55 Check DL and Check JH: Significant palliative benefits of single agent mifepristone for advanced lung cancer that previously failed standard therapy. Med Clin Sci 1: 1-5, 2019. DOI: 10.33425/2690-5191.1011

56 Check DL, Check JH, Poretta T, Aikins $\mathrm{J}$ and Wilson C: Prolonged high-quality life in patients with non-small cell lung cancer treated with mifepristone who advanced despite osimertinib. Cancer Sci Res 3: 1-5, 2020.

57 Check JH, Check D, Srivastava MD, Poretta T and Aikins JK: Treatment with mifepristone allows a patient with end-stage pancreatic cancer in hospice on a morphine drip to restore a decent quality of life. Anticancer Res 40(12): 6997-7001, 2020. PMID: 33288594. DOI: 10.21873/anticanres.14724

58 Check JH, Check D, Poretta T and Wilson C: Palliative benefits of oral mifepristone for the treatment of metastatic fibroblastic osteosarcoma. Anticancer Res 41(4): 2111-2115, 2021. PMID: 33813421. DOI: $10.21873 /$ anticanres. 14982

59 Check JH, Check DL and Dougherty MP: Progesterone receptor antagonists - a novel treatment for severe hyponatremia from the endocrine paraneoplastic syndrome. J Endocrinol Res 3: 4043, 2021. DOI: $10.30564 /$ jer.v3i2.3611

60 Check JH, Wilson C, Cohen R and Sarumi M: Evidence that Mifepristone, a progesterone receptor antagonist, can cross the blood brain barrier and provide palliative benefits for glioblastoma multiforme grade IV. Anticancer Res 34(5): 23852388, 2014. PMID: 24778047.

61 Mifsud W and Bateman A: Membrane-bound progesterone receptors contain a cytochrome b5-like ligand-binding domain. Genome Biol 3(12): RESEARCH0068, 2002. PMID: 12537557. DOI: $10.1186 / \mathrm{gb}-2002-3-12$-research0068 
62 Cahill MA, Jazayeri JA, Catalano SM, Toyokuni S, Kovacevic $\mathrm{Z}$ and Richardson DR: The emerging role of progesterone receptor membrane component 1 (PGRMC1) in cancer biology. Biochim Biophys Acta 1866(2): 339-349, 2016. PMID: 27452206. DOI: 10.1016/j.bbcan.2016.07.004

63 Ahmed IS, Rohe HJ, Twist KE and Craven RJ: Pgrmc1 (progesterone receptor membrane component 1) associates with epidermal growth factor receptor and regulates erlotinib sensitivity. J Biol Chem 285(32): 24775-24782, 2010. PMID: 20538600. DOI: $10.1074 /$ jbc.M110.134585

64 Szczesna-Skorupa E and Kemper B: Progesterone receptor membrane component 1 inhibits the activity of drugmetabolizing cytochromes $\mathrm{P} 450$ and binds to cytochrome P450 reductase. Mol Pharmacol 79(3): 340-350, 2011. PMID: 21081644. DOI: $10.1124 / \mathrm{mol} .110 .068478$

65 Kabe Y, Nakane T, Koike I, Yamamoto T, Sugiura Y, Harada E, Sugase K, Shimamura T, Ohmura M, Muraoka K, Yamamoto A, Uchida T, Iwata S, Yamaguchi Y, Krayukhina E, Noda M, Handa H, Ishimori K, Uchiyama S, Kobayashi T and Suematsu M: Haemdependent dimerization of PGRMC1/Sigma-2 receptor facilitates cancer proliferation and chemoresistance. Nat Commun 7: 11030, 2016. PMID: 26988023. DOI: $10.1038 /$ ncomms 11030

66 Peluso JJ, Pappalardo A, Losel R and Wehling M: Expression and function of PAIRBP1 within gonadotropin-primed immature rat ovaries: PAIRBP1 regulation of granulosa and luteal cell viability. Biol Reprod 73(2): 261-270, 2005. PMID: 15814896. DOI: $10.1095 /$ biolreprod.105.041061

67 Mir SU, Schwarze SR, Jin L, Zhang J, Friend W, Miriyala S, St Clair D and Craven RJ: Progesterone receptor membrane component 1/Sigma-2 receptor associates with MAP1LC3B and promotes autophagy. Autophagy 9(10): 1566-1578, 2013. PMID: 24113030. DOI: 10.4161 /auto.25889

68 Kim JY, Kim SY, Choi HS, Kim MK, Lee HM, Jang YJ and Ryu CJ: Progesterone Receptor Membrane Component 1 suppresses the p53 and $\mathrm{Wnt} / \beta$-catenin pathways to promote human pluripotent stem cell self-renewal. Sci Rep 8(1): 3048, 2018. PMID: 29445107. DOI: 10.1038/s41598-018-21322-Z

69 Zhang Y, Ruan X, Willibald M, Seeger H, Fehm T, Neubauer H and Mueck AO: May progesterone receptor membrane component 1 (PGRMC1) predict the risk of breast cancer? Gynecol Endocrinol 32(1): 58-60, 2016. PMID: 26303031. DOI: 10.3109/09513590.2015.1078303

70 Willibald M, Wurster I, Meisner C, Vogel U, Seeger H, Mueck $\mathrm{AO}$, Fehm $\mathrm{T}$ and Neubauer H: High Level of Progesteron Receptor Membrane Component 1 (PGRMC 1) in Tissue of Breast Cancer Patients is Associated with Worse Response to Anthracycline-Based Neoadjuvant Therapy. Horm Metab Res 49(8): 595-603, 2017. PMID: 28701017. DOI: 10.1055/s-0043113635

71 Hampton KK, Stewart R, Napier D, Claudio PP and Craven RJ: PGRMC1 elevation in multiple cancers and essential role in stem cell survival. Adv Lung Cancer (Irvine) 4(3): 37-51, 2015. PMID: 27867772. DOI: 10.4236/alc.2015.43006
72 Mir SU, Ahmed IS, Arnold S and Craven RJ: Elevated progesterone receptor membrane component $1 /$ sigma-2 receptor levels in lung tumors and plasma from lung cancer patients. Int J Cancer 131(2): E1-E9, 2012. PMID: 21918976. DOI: 10.1002/ijc.26432

73 Ruan X, Zhang Y, Mueck AO, Willibald M, Seeger H, Fehm T, Brucker $S$ and Neubauer $H$ : Increased expression of progesterone receptor membrane component 1 is associated with aggressive phenotype and poor prognosis in ER-positive and negative breast cancer. Menopause 24(2): 203-209, 2017. PMID: 27749742. DOI: 10.1097/GME.0000000000000739

74 Peluso JJ, Liu X, Saunders MM, Claffey KP and Phoenix K: Regulation of ovarian cancer cell viability and sensitivity to cisplatin by progesterone receptor membrane component-1. J Clin Endocrinol Metab 93(5): 1592-1599, 2008. PMID: 18319313. DOI: $10.1210 /$ jc.2007-2771

75 Tsai HW, Ho CL, Cheng SW, Lin YJ, Chen CC, Cheng PN, Yen CJ, Chang TT, Chiang PM, Chan SH, Ho CH, Chen SH, Wang YW, Chow NH and Lin JC: Progesterone receptor membrane component 1 as a potential prognostic biomarker for hepatocellular carcinoma. World J Gastroenterol 24(10): 11521166, 2018. PMID: 29563759. DOI: 10.3748/wjg.v24.i10.1152

76 Ponikwicka-Tyszko D, Chrusciel M, Stelmaszewska J, Bernaczyk P, Chrusciel P, Sztachelska M, Scheinin M, Bidzinski M, Szamatowicz J, Huhtaniemi IT, Wolczynski S and Rahman NA: Molecular mechanisms underlying mifepristone's agonistic action on ovarian cancer progression. EBioMedicine 47: 170183, 2019. PMID: 31466918. DOI: 10.1016/j.ebiom.2019.08.035

77 Check D, Check JH and Wilson C: Alpelisib combined with low dose mifepristone for treating advanced breast cancer may cause hypokalemia even when this complication does not occur from single use of the anticancer agents. Cancer Sci Res 3: 1-4, 2020.

78 Ji Y, Rankin C, Grunberg S, Sherrod AE, Ahmadi J, Townsend JJ, Feun LG, Fredericks RK, Russell CA, Kabbinavar FF, Stelzer KJ, Schott A and Verschraegen C: Double-blind phase III randomized trial of the antiprogestin agent mifepristone in the treatment of unresectable meningioma: SWOG S9005. J Clin Oncol 33(34): 4093-4098, 2015. PMID: 26527781. DOI: 10.1200/JCO.2015.61.6490

79 Craven RJ: Ag-205 for the treatment of breast cancer. Pharmacology and Nutritional Sciences Faculty Patents 52, 2017. Available at: http://uknowledge.uky.edu/pharmacol_patents/52 [Last accessed on October 29, 2021]

80 Tohme S, Simmons RL and Tsung A: Surgery for cancer: a trigger for metastases. Cancer Res 77(7): 1548-1552, 2017. PMID: 28330928. DOI: 10.1158/0008-5472.CAN-16-1536

Received October 5, 2021

Revised October 28, 2021

Accepted October 29, 2021 